\title{
academicJournals
}

Vol. 8(42), pp. 3650-3655, 15 October, 2014

DOI: 10.5897/AJ MR2014.7021

Artic le Number. D69409848183

ISSN 1996-0808

Copyright (C) 2014

African Journal of Microbiology Research

Author(s) retain the copyright of this article

http://www.academic joumals.org/AJ MR

\section{Effects of fertilizers and soil amendments on the incidence of Sclerotinia stem rot in Indian mustard (Brassica juncea L.)}

\author{
Shri Kishan Bairwa ${ }^{1 *}$, Shankar Lal Godara ${ }^{2}$, Susheela Meena ${ }^{3}$, Narendra Kumar Jatav ${ }^{4}$ and \\ Ramesh Chand Bairwa ${ }^{5}$ \\ ${ }^{1}$ A.R.S., S.K. Rajasthan Agricultural University, Sriganganagar-335001. Rajasthan, India. \\ ${ }^{2}$ ARS, S.K. Rajasthan Agricultural University, Bikaner-334006, Rajasthan, India. \\ ${ }^{3}$ F/10, Khora House, Nandpuri Colony, Jagatpura Road, Malviya Nagar, Jaipur - 302017 (Raj.), India. \\ ${ }^{4}$ P.D. College, Gajsinghpur, Sriganganagar, Rajasthan, India. \\ ${ }^{5}$ College of Agriculture, S.K. Rajasthan Agricultural University, Bikaner-334006. Rajasthan, India.
}

Received 18 July, 2014; Accepted 29 September, 2014

\begin{abstract}
Indian mustard [Brassica juncea (L.)] is a major oilseed crop, grown in rabi season in India. Sclerotinia stem rot, stem blight or white rot disease caused by Sclerotinia sclerotiorum (Lib.) de Bary is a serious problem in mustard crop in Northern India. The present investigations were undertaken to understand the role of fertilizers and organic amendments on disease development in mustard crop under field conditions. In experiment 1 , the effect of nitrogen, phosphorus and potash fertilizers with different levels on the development of Sclerotinia stem rot and on seed yield was studied during two years. The treatment was a combination of $80 \mathrm{~kg} \mathrm{~N}, 60 \mathrm{~kg} \mathrm{P}$ and $60 \mathrm{~kg} \mathrm{~K} \mathrm{ha-}{ }^{1}$ which was applied significantly superior over control (without fertilizers) in disease control $(60.42 \%)$ and increased seed yield (13.80 q ha- ${ }^{1}$ ). Application of $100 \mathrm{~kg} \mathrm{~N}$, and $60 \mathrm{~kg} \mathrm{P} \mathrm{ha-}{ }^{1}$ without $\mathrm{K}$ was found to be least effective for disease management. In experiment 2 , effect of five soil amendments, that is, mustard cake, neem cake, vermicompost, farm yard manure and sulphur on the development of Sclerotinia stem rot was studied. Neem cake applied at 1 ton ha- ${ }^{1}$ was found significantly superior with minimum disease incidence $(20.43 \%)$, minimum disease intensity $(15.00 \%)$, maximum disease control $(63.27 \%)$ and increased seed yield (14.07 $\mathrm{q} \mathrm{ha}^{-1}$ ) over control (without amendments). The vermicompost and FYM applied at 15 ton ha- ${ }^{1}$ were also found effective in minimizing disease intensity and increased seed yield.
\end{abstract}

Key words: Fertilizers, Indian mustard, soil amendments and Sclerotinia stem rot.

\section{INTRODUCTION}

Indian mustard [Brassica juncea (L.) Czern \& Coss] is a major oilseed crop grown in rabi season in various regions of India. Rapeseed and mustard are the major oilseed crops of India with oil contents ranging between

${ }^{*}$ Corresponding author. E-mail: kishan.ngr@gmail.com.

Author(s) agree that this article remain permanently open access under the terms of the Creative Commons Attribution License 4.0International License 
30 and 46\%. Among the annual edible oilseeds, rapeseed and mustard contributes about $23 \%$ in acreage and over $25 \%$ in production for the last five years in India. India holds a leading position in area and production of rapeseed and mustard, that is,5.92 million hectares and 6.78 million tonnes, respectively, with an average productivity of $1145 \mathrm{~kg}$ ha- ${ }^{1}$. The main mustard producing states in India are Rajasthan, Uttar Pradesh, Punjab, Haryana, etc. Among these states, Rajasthan stands first both in area and production, that is, 2.50 million ha and 2.97 million tonnes, respectively, with an average productivity of $1187 \mathrm{~kg}$ ha- ${ }^{1}$ (Directorate of Economics and Statistics, 2012). Rapeseed and mustard seeds are commonly used for the extraction of edible oil in Northern India. The oil content of the seeds ranges from 30 to $46 \%$. The seed is used as a condiment in the preparation of pickles and for flavouring curries and vegetables. The oil cake is mostly used as a cattle feed. The seeds, oil and oil cakes are needed not only to meet the demand for internal consumption but also for export in order to earn the much needed foreign exchange.

Sclerotinia stem rot, or stem blight or white rot caused by Sclerotinia sclerotiorum (Lib.) de Bary has become a serious problem in mustard crop in northern India. $S$. sclerotiorum is soil-borne and has a large host range inciting more than 400 plant species (Boland and Hall, 1994). Sclerotinia stem rot is an economically important yield reducing disease that has been widely reported in the last few years in India and elsewhere. The high disease incidence and severe yield losses discourage farmers to grow the crop (Krishnia et al., 2000). The disease symptoms usually appear four to six weeks after sowing or at flowering stage, when significant damage has already been done. Sudden drooping of leaves followed by drying of plants are characteristic features of the disease. This disease is gaining importance in the mustard growing areas, which may cause crop failure as the disease incidence was recorded up to $73.8 \%$ in some districts of Punjab and Haryana (Kang and Chahal, 2000; Sharma et al., 2001). In Rajasthan, the disease incidence was recorded up to $60 \%$ (Ghasolia et al., 2004; Shukla, 2005). Various soil factors, such as nutritional status of the soil play a major role in the disease incidence. Sclerotia are the primary survival structures of S. sclerotiorum and act as a source of infection for many years in the field. Balanced fertilization and amendments of soil with decomposable organic matter could be an effective method of changing the soil and rhizosphere environment. Composts enrich the soil with microflora potentially competitive or antagonistic to pathogens or release inhibitory substances or volatiles during decomposition. The control of Sclerotinia stem rot of mustard in India is mainly achieved by using fungicides and cultural methods such as crop rotation and tillage to reduce inoculums of the pathogen. Most of the conventional methods are not effective in the management of $S$. sclerotiorum thus, the present study was undertaken to find out role of fertilizer doses (NPK) and soil amendments (neem cake, mustard cake, vermicompost, farm yard manure and sulphur dust) on disease severity and yield of mustard.

\section{MATERIALS AND METHODS}

\section{Inoculum}

An isolate of S. sclerotiorum was obtained from diseased mustard plant collected from farmer's field. Small pieces of diseased tissues along with adjoining healthy area and sclerotia found in diseased stem were surface sterilized by dipping in mercuric chloride solution $(1: 1000)$ for two minutes followed by three washings with sterile water and blot dried then plated aseptically on Potato Dextrose Agar (PDA) in Petri dishes. These were incubated in BOD incubator for growth of the fungus at $27 \pm 2^{\circ} \mathrm{C}$.

Sub cultures from pure peripheral growth were made on PDA slants. The pathogenicity of the isolated fungus was proved by mixing 15 day old inoculum (grown on sterilized sorghum grains) at the rate of $50 \mathrm{~g}$ per pot in the upper $3-5 \mathrm{~cm}$ layer of the sterilized soil of each pot. The soil of the pots were moistened and covered with polythene bags and left for $24 \mathrm{~h}$ in green house. On next day, apparently healthy surface sterilized mustard seeds were sown in these pots. Re-isolations from the diseased seedlings yielded the same fungus.

\section{Mass multiplication of inoculum}

The fungus inoculum was multiplied on sterilized sorghum grains. The sorghum grains were soaked in sterilized water overnight. The excess water drained out. Forty grams of grains was taken in each $250 \mathrm{ml}$ conical flask, plugged with cotton and sterilized in an autoclave at $1.045 \mathrm{~kg} / \mathrm{cm}^{2}$ pressure for $20 \mathrm{~min}$. The sorghum grains in flasks were inoculated aseptically with 5 days old mycelial discs $(5 \mathrm{~mm})$ of the pathogen and incubated for 15 days at $20 \pm 2^{\circ} \mathrm{C}$. The inoculum was mixed in rows at the time of sowing.

Two experiments were executed during rabi season of 2007-08 and 2008-09 at the research farm of the College of Agriculture, Swami Keshwanand Rajasthan Agricultural University, Bikaner. A randomized block design was used with three replications in $4 \times 3$ $\mathrm{m}^{2}$ plots. The susceptible mustard cultivar 'varuna' was used for all experiments. All experiments were artificially inoculated with $20 \mathrm{~g}$ inoculums per meter row. All recommended agronomic practices were followed to raise the crop except fertilizers dose and organic amendments. The fertilizers and organic amendments were applied according to the treatments. Sowing of the crop was done during last week of October.

In experiment 1 the relationship of different fertilizers (NPK) and their combination with the disease development of Sclerotinia stem rot on mustard under field conditions were tested. The different treatments on combination of fertilizers $\mathrm{N}: \mathrm{P}: \mathrm{K}\left(\mathrm{kg}\right.$ ha- $\left.{ }^{1}\right)$ viz. $\mathrm{T}_{1-}$ 60:30:30, $\mathrm{T}_{2}-60: 30: 60, \mathrm{~T}_{3}-60: 60: 30, \mathrm{~T}_{4}-60: 60: 60, \mathrm{~T}_{5}-80: 30: 30, \mathrm{~T}_{6-}$ 80:30:60, $\mathrm{T}_{7}-80: 60: 30, \mathrm{~T}_{8}-80: 60: 60, \mathrm{~T}_{9}-100: 30: 30, \mathrm{~T}_{10}-100: 30: 60$, $\mathrm{T}_{11}-100: 60: 30, \mathrm{~T}_{12}-100: 60: 60, \mathrm{~T}_{13}-100: 60: 0$ and $\mathrm{T}_{14}-80: 30: 0$ were applied with control plot ( $T_{15}$-without fertilizers). Half quantity of nitrogen, full quantity of phosphorus and potash were applied at the sowing time and remaining half quantity of nitrogen were applied in two splits at first and second irrigation.

In experiment 2, the effect of different soil amendments and their doses on disease development of Sclerotinia stem rot was studied. $\mathrm{T}_{1} \& \mathrm{~T}_{2}$-mustard cake $1 \& 2$ tons ha- ${ }^{1}, \mathrm{~T}_{3} \& \mathrm{~T}_{4}$-neem cake $0.5 \& 1$ ton ha- ${ }^{1}, T_{5} \& T_{6}$-vermicompost $10 \& 15$ tons ha- ${ }^{1}, T_{7} \& T_{8}-F Y M 10 \& 15$ tons ha- ${ }^{1}$ and $\mathrm{T}_{9} \& \mathrm{~T}_{10}$-sulphur $30 \& 60 \mathrm{~kg}$ ha- ${ }^{1}$ were compared against a control plot ( $\mathrm{T}_{11}$-without organic amendments). All the 
amendments were applied in the plots before sowing of the mustard crop.

The observations of disease intensity, incidence and seed yield were recorded on plot basis. Disease intensity and incidence were recorded after 75 to 90 days after sowing. The results of experiments were statistically analyzed by using appropriate designs. To assess the Sclerotinia rot intensity, the rating (0-4) scale (Lesovoi et al., 1987; Sansford, 1995) was followed. 0 for healthy (No visible lesion), 1 for $0.1-2.0 \mathrm{~cm}$ lesion length on the stem, 2 for $2.1-4.0 \mathrm{~cm}$ lesion length on the stem, 3 for $4.1-6.0 \mathrm{~cm}$ lesion length on the stem and 4 for more than $6 \mathrm{~cm}$ lesion length on the stem or complete griddle plant. The length of lesion on infected stem was considered for recording the disease intensity (Sharma, 1987). The infected area was calculated from five randomly selected plants in each plot and then the average for each treatment was worked out. Percent disease intensity was calculated by using the formula [(sum of individual ratings/no. of plants observed $\times$ maximum disease rating) $\times 100$ ]. The percent disease control was calculated by using the formula [(Disease in control Disease in treatment/ Disease in Control) $\times$ 100] (McKinney, 1923).

\section{RESULTS AND DISCUSSION}

Experiment 1 revealed that the application of $80 \mathrm{~kg} \mathrm{~N}, 60$ $\mathrm{kg} P$ and $60 \mathrm{~kg} \mathrm{~K} \mathrm{ha-}{ }^{1}$ was significantly superior in percent disease control $(p=0.05)$ as well as in seed yield $\left(13.80 \mathrm{q} \mathrm{ha}^{-1}\right)(p=0.05)$ over control (Table 1$)$. Application of $100 \mathrm{~kg} \mathrm{~N}$, and $60 \mathrm{~kg} \mathrm{P}$ ha- ${ }^{1}$ without $\mathrm{K}$ was least effective for disease control (4.17\%). Application of $80 \mathrm{~kg}$ $\mathrm{N}, 30 \mathrm{~kg} \mathrm{P}$ without potash resulted in the lowest seed yield (6.59 q ha- $\left.{ }^{1}\right)$. Table 1 suggests that application of more than $80 \mathrm{~kg} \mathrm{~N}$ ha-1 increase disease severity and reduced the percent disease control. This observation is in accordance with earlier findings of Gupta et al. (2004) that reported that increased nitrogen levels of nitrogen (60 to $90 \mathrm{~kg} \mathrm{ha-}{ }^{1}$ ) in soil led to significant increase in Sclerotinia stem rot disease incidence in mustard. In addition, Rathore and Chandawat (2003) found that increased nitrogen fertilization reduces seed yield and stover yield and increase susceptibility of blond psyllum to Peronospora alta, causing downy mildew. Chattopadhyay et al. (2002) observed that soil application of $\mathrm{K}$ fertilizer in $\mathrm{S}$. sclerotiorum infected fields reduced the disease incidence in mustard. Banyal et al. (2008) reported nitrogen fertilization enhanced the development of collar rot caused by Sclerotium rolfsii in tomato, whereas phosphorus and potassium fertilization decreased the disease. Potassium $(K)$ is essential for the synthesis of proteins, starch and cellulose in plants. Cellulose is a primary component of cell walls, and $\mathrm{K}$ deficiency causes cell walls to become leaky, resulting in high sugar (starch precursor) and amino acid (protein building blocks) concentrations in the plant. Nitrogen (N) is a key component of amino acids; therefore, an excessive supply of $\mathrm{N}$ can bring about higher amounts of amino acids and other $\mathrm{N}$-containing compounds in plant tissues. These mineral imbalances lower resistance to fungal diseases by creating a more favorable environment for pathogens (Span and Schumann, 2010).
Experiment 2 revealed that the addition of neem cake, vermicompost, FYM, organic sulphur and mustard cake significantly decreased the disease intensity $(p=0.05)$ in mustard as compared to the control. The addition of neem cake was significantly superior in disease control $(p=0.05)$ as well as in increasing seed yield (Table 2). These findings are in agreement with those of Shivpuri et al. (1997) and Kapoor et al. (2006) who reported that neem based pesticides were highly effective against Fusarium oxysporium f.sp. pisi, F. solani f. sp. pisi and S. sclerotiorum. Neem cake possibly enhances the disease control by release of volatile substances during decomposition that induced disease resistance or tolerance on the root surface (Singh, 1983). It is a wellknown fact that cakes improve physio-chemical properties of the soil and increase the vigour of the crop by supplying nutrients and promoting anti-microbial populations in the rhizosphere (Sharma and Sharma, 1986). Handoro et al. (2001) reported that application of soil amendments Neemax, FYM and sheep manure to pea crops decreased the disease incidence to $S$. sclerotiorum and increased seed yield. According to Tripathi et al. (2010), neem cake extract, mustard cake extract and farm yard manure extract reduces the mycelial growth of S. sclerotiorum. Sharma et al. (2011) found that the application of mustard cake reduced the stem rot incidence and increases seed yield in cauliflower. Generally, the integration of organic amendments and biocontrol agents have been found to improve the plant health in various crops (Rana et al., 2010; Chawla and Gangopadhyay, 2010; Yadav et al., 2013).

Thus, it was concluded that use of $\mathrm{N}$ fertilizer more than $80 \mathrm{~kg}$ ha-1 increases Sclerotinia stem rot while proper application of $\mathrm{K}$ fertilizer and addition of organic amendments slowed down the Sclerotinia stem rot in mustard. Hence, balanced fertilizers and organic amendments are necessary for successful management of white stem rot of mustard and improve physiochemical properties of the soil, increase the vigour of the plant by supplying certain nutrients and encourage antimicrobial population in the rhizosphere apart from providing reasonable disease control in the field experiments.

\section{Conflict of Interest}

The author(s) have not declared any conflict of interests.

\section{ACKNOWLEDGEMENT}

The authors are grateful to the Head, Department of Plant Pathology and Dean, College of Agriculture, S.K. Rajasthan Agricultural University, Bikaner for providing necessary facilities during the course of investigation. 
Table 1. Effect of fertilizer levels on disease development of Sclerotinia stem rot of Indian mustard under field conditions.

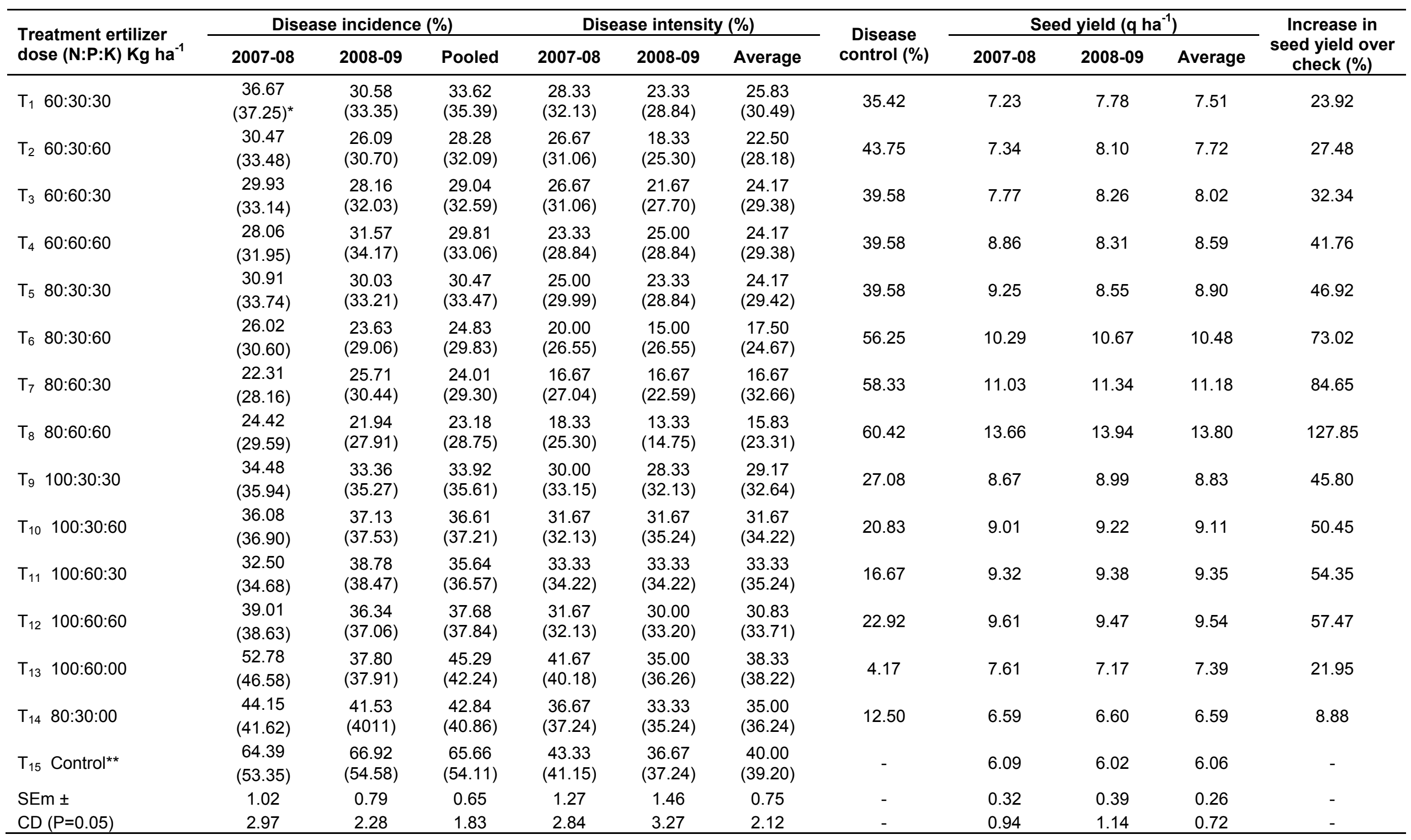

*Figures in parentheses are angular transformed values, ** without fertilizers. 
Table 2. Effect of soil amendments on disease development of Sclerotinia stem rot of Indian mustard under field conditions.

\begin{tabular}{|c|c|c|c|c|c|c|c|c|c|c|c|c|}
\hline \multirow{2}{*}{ Treatment } & \multirow{2}{*}{ Dose } & \multicolumn{3}{|c|}{ Disease incidence (\%) } & \multicolumn{3}{|c|}{ Disease intensity (\%) } & \multirow{2}{*}{$\begin{array}{c}\text { Disease } \\
\text { control } \\
(\%) \\
\end{array}$} & \multicolumn{3}{|c|}{ Seed yield $\left(\mathrm{q} \mathrm{ha} \mathrm{h}^{-1}\right)$} & \multirow{2}{*}{$\begin{array}{c}\text { Increase in } \\
\text { seed yield over } \\
\text { check (\%) }\end{array}$} \\
\hline & & 2007-08 & 2008-09 & Pooled & 2007-08 & 2008-09 & Pooled & & 2007-08 & 2008-09 & Pooled & \\
\hline $\mathrm{T}_{1}$ Mustard cake & 1 ton ha ${ }^{-1}$ & $\begin{array}{c}34.97 \\
(36.24)^{*}\end{array}$ & $\begin{array}{c}38.63 \\
(38.41)^{*}\end{array}$ & $\begin{array}{c}36.80 \\
(37.32)^{*}\end{array}$ & $\begin{array}{c}30.00 \\
(23.20)\end{array}$ & $\begin{array}{c}31.67 \\
(34.22)\end{array}$ & $\begin{array}{c}30.83 \\
(33.71)\end{array}$ & 24.49 & 8.19 & 7.69 & 7.94 & 12.98 \\
\hline $\mathrm{T}_{2}$ Mustard cake & 2 tons ha $^{-1}$ & $\begin{array}{c}29.58 \\
(32.93)\end{array}$ & $\begin{array}{c}32.12 \\
(34.48)\end{array}$ & $\begin{array}{c}30.85 \\
(33.71)\end{array}$ & $\begin{array}{c}26.67 \\
(31.06)\end{array}$ & $\begin{array}{c}30.00 \\
(33.20)\end{array}$ & $\begin{array}{c}28.33 \\
(32.13)\end{array}$ & 30.61 & 8.64 & 8.42 & 8.53 & 21.32 \\
\hline $\mathrm{T}_{3}$ Neem cake & 0.5 ton $\mathrm{ha}^{-1}$ & $\begin{array}{c}25.28 \\
(30.17)\end{array}$ & $\begin{array}{c}23.49 \\
(28.98)\end{array}$ & $\begin{array}{c}24.39 \\
(29.57)\end{array}$ & $\begin{array}{c}20.00 \\
(26.55)\end{array}$ & $\begin{array}{c}20.00 \\
(26.55)\end{array}$ & $\begin{array}{c}20.00 \\
(26.55)\end{array}$ & 51.02 & 12.43 & 12.03 & 12.23 & 73.98 \\
\hline $\mathrm{T}_{4}$ Neem cake & 1 ton ha ${ }^{-1}$ & $\begin{array}{c}21.97 \\
(27.90)\end{array}$ & $\begin{array}{c}18.70 \\
(25.54)\end{array}$ & $\begin{array}{c}20.34 \\
(26.72)\end{array}$ & $\begin{array}{c}15.00 \\
(22.78)\end{array}$ & $\begin{array}{c}15.00 \\
(22.78)\end{array}$ & $\begin{array}{c}15.00 \\
(22.78)\end{array}$ & 63.27 & 14.19 & 13.95 & 14.07 & 100.18 \\
\hline $\mathrm{T}_{5}$ Vermicompost & 10 tons ha ${ }^{-1}$ & $\begin{array}{c}35.92 \\
(36.80)\end{array}$ & $\begin{array}{c}37.33 \\
(37.63)\end{array}$ & $\begin{array}{c}36.63 \\
(37.22)\end{array}$ & $\begin{array}{c}23.33 \\
(28.84)\end{array}$ & $\begin{array}{c}33.33 \\
(35.24)\end{array}$ & $\begin{array}{c}28.33 \\
(32.04)\end{array}$ & 30.61 & 11.08 & 10.52 & 10.80 & 53.67 \\
\hline $\mathrm{T}_{6}$ Vermicompost & 15 tons ha $^{-1}$ & $\begin{array}{c}24.48 \\
(29.63)\end{array}$ & $\begin{array}{c}32.20 \\
(34.49)\end{array}$ & $\begin{array}{c}28.34 \\
(32.06)\end{array}$ & $\begin{array}{c}18.33 \\
(25.30)\end{array}$ & $\begin{array}{c}28.33 \\
(32.13)\end{array}$ & $\begin{array}{c}23.33 \\
(28.71)\end{array}$ & 42.86 & 12.15 & 11.90 & 12.03 & 71.10 \\
\hline $\mathrm{T}_{7} \mathrm{FYM}$ & 10 tons ha ${ }^{-1}$ & $\begin{array}{c}41.94 \\
(40.34)\end{array}$ & $\begin{array}{c}44.18 \\
(41.61)\end{array}$ & $\begin{array}{c}43.06 \\
(40.99)\end{array}$ & $\begin{array}{c}33.33 \\
(35.24)\end{array}$ & $\begin{array}{c}33.33 \\
(35.24)\end{array}$ & $\begin{array}{c}34.17 \\
(35.75)\end{array}$ & 16.33 & 10.90 & 9.19 & 10.05 & 42.94 \\
\hline $\mathrm{T}_{8} \mathrm{FYM}$ & 15 tons ha ${ }^{-1}$ & $\begin{array}{c}36.19 \\
(36.96)\end{array}$ & $\begin{array}{c}37.19 \\
(37.56)\end{array}$ & $\begin{array}{c}36.69 \\
(37.26)\end{array}$ & $\begin{array}{c}31.67 \\
(34.22)\end{array}$ & $\begin{array}{c}31.67 \\
(34.22)\end{array}$ & $\begin{array}{c}31.67 \\
(34.22)\end{array}$ & 22.45 & 11.94 & 11.76 & 11.85 & 68.65 \\
\hline $\mathrm{T}_{9}$ Sulphur & $30 \mathrm{~kg} \mathrm{ha}^{-1}$ & $\begin{array}{c}30.99 \\
(33.80)\end{array}$ & $\begin{array}{c}30.18 \\
(33.29)\end{array}$ & $\begin{array}{c}30.58 \\
(35.55)\end{array}$ & $\begin{array}{c}21.67 \\
(27.70)\end{array}$ & $\begin{array}{c}25.00 \\
(29.99)\end{array}$ & $\begin{array}{c}23.33 \\
(28.84)\end{array}$ & 42.86 & 8.75 & 8.81 & 8.78 & 24.90 \\
\hline $\mathrm{T}_{10}$ Sulphur & $60 \mathrm{~kg} \mathrm{ha}^{-1}$ & $\begin{array}{c}26.30 \\
(30.81)\end{array}$ & $\begin{array}{c}23.30 \\
(28.84)\end{array}$ & $\begin{array}{c}24.80 \\
(39.82)\end{array}$ & $\begin{array}{c}20.00 \\
(26.55)\end{array}$ & $\begin{array}{c}21.67 \\
(27.70)\end{array}$ & $\begin{array}{c}20.83 \\
(27.13)\end{array}$ & 48.98 & 9.05 & 10.19 & 9.62 & 36.83 \\
\hline $\mathrm{T}_{11}$ Control $^{\star *}$ & & $\begin{array}{c}60.34 \\
(50.95)\end{array}$ & $\begin{array}{c}61.91 \\
(51.87)\end{array}$ & $\begin{array}{c}61.13 \\
(51.41)\end{array}$ & $\begin{array}{c}38.33 \\
(38.23)\end{array}$ & $\begin{array}{c}43.33 \\
(41.15)\end{array}$ & $\begin{array}{c}40.83 \\
(39.69)\end{array}$ & - & 6.99 & 7.07 & 7.03 & - \\
\hline $\mathrm{SEm} \pm$ & & 0.96 & 1.22 & 0.78 & 1.40 & 1.21 & 0.60 & - & 0.40 & 0.40 & 0.29 & - \\
\hline$C D(P=0.05)$ & & 2.84 & 3.59 & 2.24 & 2.68 & 2.31 & 1.72 & - & 1.18 & 1.18 & 0.82 & - \\
\hline
\end{tabular}

*Figures in parentheses are angular transformed values, ${ }^{* *}$ without soil amendments.

\section{REFERENCES}

Banyal DK, Mankotia V, Sugha SK (2008). Soil characteristics and their relation to development of tomato collar rot caused by Sclerotium rolfsii. Indian Phytopathol. 61(1):103-107.

Boland GJ, Hall R (1994). Index of plant hosts of Sclerotinia sclerotiorum. Can. J. Plant Pathol. 16:93-108.

Chattopadhyay C, Meena PD, Kumar S (2002). Management of Sclerotinia rot of Indian mustard using eco-friendly strategies. J. Mycol. Plant Pathol. 32(2):194-200.

Chawla N, Gangopadhyay S (2010). Integration of organic amendments and bioagents in suppressing cumin wilt caused by Fusarium oxysporum f. sp. cumini. Indian Phytopathol. 62(2):209-216

Directorate of Economics and Statistics (2012). Agricultura Statistics At a Glance, Department of Agriculture and Cooperation. Govt. of India. pp. 101-102.

Ghasolia RP, Shivpuri A, Bhargava AK (2004). Sclerotinia rot of Indian mustard in Rajasthan. Indian Phytopathol. 57(1):76-79.

Gupta R, Awasthi RP, Kolte SJ (2004). Effect of sowing date and weather on development of white rust (Albugo candida) in rapeseed-mustard. J. Mycol. Plant Pathol. 34(2):441-444. Handoro F, Sandhu KS and Singh PP (2001). Management of white rot of pea through organic amendments and fungicides Plant Dis. Res. 16 (2):193-197.

Kang IS, Chahal SS (2000). Prevalence and incidence of white rot of rapeseed and mustard incited by Sclerotinia sclerotiorum in Punjab. Plant Dis. Res. 15: 232-253.

Kapoor AS, Paul YS, Singh A (2006). Integrated management of white rot and root rot- wilt disease complex pf pea. Indian Phytopathol. 59 (4):467-474.

Krishnia SK, Meena PD, Chattopadhyay C (2000). Seed-yield and yield- attributes of Indian mustard affected by Sclerotinia rot. J. Mycol. Plant Pathol. 30: 265.

Lesovoi MP, Parfenyuk Al, Kondrafyuk OK (1987). A method 
of identifying and selecting sunflower resistant to pathogen of white rot and grey mould. Mykollogiya Fitopathol. 21:273-278.

Mckinney $\mathrm{HH}$ (1923). A new system of grading plant diseases. J. Agric. Res. 26:195-218.

Rana S, Sharma SK, Sharma JN (2010). Integration of cultural, chemical and biocontrol methods in management of white root rot of apples. Indian Phytopathol. 63:207-211.

Rathore BS, Chandawat MS (2003). Influence of irrigation, row orientation and nitrogen on downy mildew of blond psyllum. Indian Phytopathol. 56(4):453-456.

Sansford C (1995). Oilseed rape: Development of stem rot (Sclerotinia sclerotiorum) and its effect on yield. In Proc. IX International Rapeseed Congress. Today and Tomorrow, Cambridge, U.K. 2: 634636.

Sharma AK (1987). Evaluation of fungicides for the control of Sclerotinia rot of pea. Indian Phytopathol. 40:399-400.

Sharma P, Meena PD, Rai PK, Kumar S, Siddiqui SA (2011). Evaluation of soil amendments, botanical and fungicide against Sclerotinia sclerotiorum causing stem rot of Indian mustard. J. Mycol.Plant Pathol. 41(1):151 (Abstr).

Sharma RC, Sharma SL (1986). Effect of soil amendments and artificial defoliation of infected leaves on sclerotinia stalk rot of cauliflower. Indian J. Plant Pathol. 4:126-128.
Sharma S, Yadav JL, Sharma GR (2001). Effect of various agronomic practices on the incidence of white rot of Indian mustard caused by Sclerotinia sclerotiorum. J. Mycol. Plant Pathol. 31(1): 83-84.

Shivpuri A, Sharma OP, Jhamaria SL (1997). Fungitoxic properties of plant extracts against pathogenic fungi. J. Mycol. Plant Pathol. 27:2431.

Shukla AK (2005). Estimation of yield losses to Indian mustard (Brassica juncea) due to Sclerotinia stem rot. J. Phytol. Res. 18(2):267-268

Singh RS (1983). Organic amendments for root disease control through management of soil microbiota and host. Indian J. Plant Pathol. 13:11-16.

Span TM, Schumann AW (2010). Mineral Nutrition contributes to plant disease and pest resistance. University of Florida document HS1181. Published on-line at http://edis.ifas.ufl.edu

Tripathi SC, Tripathi AK, Chaturvedi C (2010). Effect of different organic amendments on the growth of Sclerotinia sclerotiorum (Lib.) de Bary in vitro. Vegetos 23(2):191-193.

Yadav BC, Gupta RP, Singh SK (2013). Efficacy of soil amendment on seed germination, web blight intensity and yield of Frenchbean (Phaseolus vulgaris). Indian J. Agric. Sci. 83: 859-61. 